Egypt. Acad. J. Biolog. Sci., 13(1):1-8 (2020)

Egyptian Academic Journal of Biological Sciences

A. Entomology

ISSN 1687- 8809

http://eajbsa.journals.ekb.eg/

\title{
Evaluation Efficiency Sticky Traps on Attraction Bemisia tabaci (Gennadius) on Squash Plants under Greenhouse Conditions
}

\author{
Amna, M. H. Maklad \\ Plant Protection Research Institute, ARC, Dokki, Giza, Egypt \\ Email: Dr.amnamaklad@yahoo.com
}

\begin{abstract}
ARTICLE INFO
ABSTRACT

Article History

Received:15/12/2019

Accepted:19/1/2020

Keywords:

Sticky traps,

Bemisia tabaci,

Cucurbita pepo L.,

Greenhouse

This study was carried out to evaluate efficiency sticky traps on attraction Bemisia tabaci (Gennadius) on squash plants Cucurbita pepo L. (three squash varieties i.e. Arkan, Sama 740 and Andro 174) under greenhouse conditions at Perkash (Giza governorate) during 2017, 2018 seasons. This study contains three experiments, The first experiment aimed to evaluate the efficiency color of the sticky trap on attraction $B$. tabaci through comparison between four colors (yellow, blue, red and white). This experiment was carried out on squash plants during the period (February March). Results showed that the traps which have yellow color more efficiency than others which have (blue, red, and white) color, respectively. The second experiment aimed to evaluate the efficiency height of the yellow sticky trap on attraction $B$. tabaci through comparison between four heights $(2 \mathrm{~m}, 1.5 \mathrm{~m}, 1 \mathrm{~m}$ and $0.5 \mathrm{~m})$ above the ground. And this experiment was carried out on squash plants during the period (April - May). Results showed that the trap which has $2 \mathrm{~m}$ height above the ground more efficiency than others which have $(1.5 \mathrm{~m}, 1 \mathrm{~m}$ and $0.5 \mathrm{~m})$ heights, respectively. The third experiment aimed to evaluation efficiency orientation of the yellow sticky trap on attraction B. tabaci through comparison between four orientations (North, South, East and West). And this experiment was carried out on squash plants during the period (June - July). Results showed that had no clear effect of the trap orientation on attraction B. tabaci.
\end{abstract}

\section{INTRODUCTION}

Squash (Cucurbita pepo L.) fruits are used for local consumption and for export. They contain some nutritional compounds for human feeding such as the moderate quantity of mineral salts, it is eaten cocked as an immature fruit, which is rich with fibers and vitamins or consumed for the mature seed, which is a good source of fats and protein (Abdein, 2016). It has a high economic value, and a nutritive food source especially vitamins and is one of the most popular vegetables grown in Egypt (Shehata et al., 2009).

Squash plants infested by a large scale of insects belong to many orders and families such as two-spotted spider mite, aphids and whitefly (El-Dars et al., 2013). The last pest whitefly Bemisia tabaci (Gennadius) causes numerous damage in both quantity and quality for the crop directly by plant juice to loosen or indirectly by plant disease-transmitting (Abdel-Salam et al., 1982; Geoghiou, 1990; Masaki et al., 1991 and Ibrahim, 2005). Also, 
more than 200 host plant species were infested by these pests (Abdallah et al., 2014). A number of vegetable crops such as tomato, squash, eggplant, cucumber were also subject to Tetranychus urticae Koch (Acari: Tetranychidae) infestations during summer plantation causing numerous injuries and yield losses (Kherebe et al., 1984; Heikal and Ali, 2000 and Faris et al., 2004). The whitefly, Bemisia tabaci (Gennadius) (Hemiptera: Aleyrodidae) caused crop losses by transmitting up to 150 virus species and by inducing plant disorders as likely as squash silver leaf (Polston et al., 2014). Moreover, whitefly secreted honeydew on the leaf surface, which leads to the growth of sooty mold fungi, then reduced the efficiency of leaves during photosynthesis processes (Burger et al., 1988).

Sticky traps still consider the best method used to control and predict the infestation by $B$. tabaci on different crops. In addition, consider the method which more efficiency to control this insect. Shen and Ren (2003) reported that the best method to trap B. tabaci adults in the jasmine fields was using a yellow card. Dan and Horowitz (1984) found that yellow sticky traps were useful to monitor $B$. tabaci population in the rose field and some ornamental plants.

This study was carried out to evaluation efficiency sticky traps on attraction $B$. tabaci on squash plants under greenhouse conditions. Also, this study was carried out during 2017, 2018 seasons Perkash region (Giza governorate) and this study contain three experiments:

First experiment aimed to evaluation efficiency color of the sticky trap on attraction B. tabaci through comparison between four colors (yellow, blue, red and white), Second experiment aimed to evaluation efficiency height of the yellow sticky trap on attraction $B$. tabaci through comparison between four heights $(2 \mathrm{~m}, 1.5 \mathrm{~m}, 1 \mathrm{~m}$, and $0.5 \mathrm{~m})$ above the ground. And the third experiment aimed to evaluation efficiency orientation of the yellow sticky trap on attraction B. tabaci through comparison between four orientations (North, South, East and West).

\section{MATERIALS AND METHODS}

\section{Experimental Design:}

The first experiment aimed to evaluation the efficiency color of the sticky trap on attraction B. tabaci through comparison between four colors (yellow, blue, red and white). This experiment was carried out on squash plants during the period (February - March) at both the two tested seasons. Greenhouses in both the two tested seasons were divided into equal four parts. Each part contains a different color of the sticky trap (yellow, blue, red and white). With same all the agricultural operations all over the two places. And checked up all the sticky traps in both the two locations biweekly to calculate the mean numbers of $B$. tabaci and recorded the data biweekly.

The second experiment aimed to evaluate the efficiency height of the yellow sticky trap on attraction $B$. tabaci through comparison between four heights $(2 \mathrm{~m}, 1.5 \mathrm{~m}, 1 \mathrm{~m}$ and $0.5 \mathrm{~m}$ ) above the ground. And this experiment was carried out on squash plants during the period (April - Mai) in both the two tested seasons. Greenhouses in both the two tested seasons divided into equal four parts. Each part contains a different height of the yellow sticky traps. With it all the agricultural operations all over the two places. And checked up all the sticky traps in both the two locations biweekly to calculate the mean numbers of B. tabaci and recorded the data biweekly.

The third experiment aimed to evaluation efficiency orientation of the yellow sticky trap on attraction B. tabaci through comparison between four orientations (North, South, East and West). And this experiment was carried out on squash plants during the period (June July) in both the two tested seasons. Greenhouses in both the two tested seasons divided into 
equal four parts. Each part contains a different orientation of the yellow sticky traps. With it all the agricultural operations all over the two places. And checked up all the yellow sticky traps in both the two locations biweekly to calculate the mean numbers of $B$. tabaci and recorded the data biweekly.

\section{Statistical Analysis:}

The mean numbers of $B$. tabaci were analyzed statistically using a one-way analysis of variance. When ANOVA indicates that significant differences were found, $(\mathrm{P}<0.05)$ means were separated by a Least Significant Differences Test (LSD), the simple correlation (r) and regression coefficient value (b) was adopted to clarifies the change in population due to change in each of the tested factors and the mean values compared with the Least Significant Differences (LSD) as well as, SAS program (SAS Institute 1988).

\section{RESULTS AND DISCUSSION}

This study was carried out to evaluate efficiency sticky traps on attraction Bemisia tabaci (Gennadius) on squash plants Cucurbita pepo L. (three squash varieties i.e. Arkan, Sama 740 and Andro 174) under greenhouse conditions at Perkash (Giza governorate) during 2017, 2018 seasons, and this study was divided into three experiments.

First Experiment:

The first experiment aimed to evaluation the efficiency color of the sticky trap on attraction B. tabaci through comparison between four colors (yellow, blue, red and white). And this experiment was carried out on squash plants during the period (February - March) at both the two tested seasons.

Data tabulated in Table (1) showed mean numbers and statically analysis of $B$. tabaci which caught by sticky traps which have different colors (yellow, blue, red and white) in greenhouses squash (three varieties of squash) in Perkash region (Giza governorate) during both of the two tested seasons 2017, 2018.

Table 1: Mean numbers of $B$. tabaci which caught by sticky traps which have different colors on squash plants at both of the two tested seasons 2017, 2018

\begin{tabular}{|c|c|c|c|c|c|c|}
\hline \multirow{2}{*}{ Trap color } & \multicolumn{5}{|c|}{ Mean numbers of Bemisia tabaci } \\
\cline { 2 - 7 } & \multicolumn{3}{|c|}{2018} \\
\cline { 2 - 7 } & Arkan & Sama 740 & Andro 174 & Arkan & Sama 740 & Andro 174 \\
\hline Yellow & $11.3^{\mathrm{b}}$ & $12.8^{\mathrm{b}}$ & $13.6^{\mathrm{b}}$ & $10.2^{\mathrm{b}}$ & $11.7^{\mathrm{a}}$ & $12.3^{\mathrm{b}}$ \\
\hline Blue & $9.4^{\mathrm{b}}$ & $10.3^{\mathrm{b}}$ & $11.3^{\mathrm{b}}$ & $8.4^{\mathrm{b}}$ & $9.5^{\mathrm{b}}$ & $10.7^{\mathrm{b}}$ \\
\hline Red & $7.3^{\mathrm{b}}$ & $9.8^{\mathrm{b}}$ & $10.5^{\mathrm{b}}$ & $6.8^{\mathrm{b}}$ & $8.2^{\mathrm{c}}$ & $9.2^{\mathrm{c}}$ \\
\hline White & $5.7^{\mathrm{b}}$ & $7.2^{\mathrm{b}}$ & $8.9^{\mathrm{b}}$ & $3.3^{\mathrm{b}}$ & $5.9^{\mathrm{a}}$ & $6.8^{\mathrm{d}}$ \\
\hline F & $\mathbf{8 5 1 . 3 6}$ & $\mathbf{7 4 8 . 0 3}$ & $\mathbf{6 8 5 . 2 5}$ & $\mathbf{5 2 5 . 0 3}$ & $\mathbf{6 3 4 . 7 3}$ & $\mathbf{4 6 5 . 5 3}$ \\
\hline L.S.D & $\mathbf{1 . 1 5 3 2}$ & $\mathbf{1 . 1 9 3 2}$ & $\mathbf{1 . 1 3 7 2}$ & $\mathbf{1 . 1 9 2 1}$ & $\mathbf{1 . 1 6 7 4}$ & $\mathbf{1 . 2 6 4 3}$ \\
\hline
\end{tabular}

Means within columns bearing different subscripts are significantly different $(P<0.05)$

Results showed that the traps which have yellow color more efficiency than others which have (blue, red, and white), respectively. Whereas for the yellow sticky traps the mean numbers of $B$. tabaci which attracted to the traps on the three squash varieties (Arkan), (Sama 740) and (Andro 147) at both of the two tested seasons 2017 and 2018 were (11,3@ 10.2), (12,8@11.7) and (13,6@ 12.3) adults/trap, respectively. For the blue sticky traps the mean numbers of $B$. tabaci which attracted to the traps on the three squash varieties at both of the two tested seasons were (9,4@ 8.4), (10.3@9.5) and (11.3@10.7) adults/trap, respectively. For the red sticky traps the mean numbers of $B$. tabaci which attracted to the traps on the 
three squash varieties at both of the two tested seasons were (7.3@ 6.8), (9.8@ 8.2) and (10.5@9.2) adults/trap, respectively. For the white sticky traps the mean numbers of $B$. tabaci which attracted to the traps on the three squash varieties at both of the two tested seasonswere(5.7@ 3.3), (7.2@ 5.9) and (8.9@6.8) adults/trap, respectively.

Statically analyses showed that were highly significant differences between mean numbers of B. tabaci, which attracted to the sticky traps, which have different colors at both the two tested seasons.

These results agree with Shen and Ren (2003) who reported that the best method to trap and control B. tabaci population in the Cucumber field was a yellow card. Soon et al. (2015) studied efficiency yellow and blue sticky traps on attractive western flower thrips and greenhouse whitefly. And reported that the yellow sticky traps were more attractive to western flower thrips and greenhouse whitefly than blue sticky traps under greenhouses conditions. Yao and Zheng (2008) studied the tropism of B. tabaci imagoes to different colors, and they found that the yellow color of the traps had the best effect on alluring the insect in a period of 44 days, and the next was green color and red color, respectively. The number of imagoes trapped by the yellow board was significantly greater than that traps by other color boards (green, red) respectively. And these results also agreements with Gong et al. (2011) who studied attractive effects of different colors on Q-type B. tabaci on squash under greenhouses conditions. And they showed that B. tabaci was strongly attracted by yellow color traps compared with other colors (blue, red) respectively.

\section{Second Experiment:}

The second experiment aimed to evaluate the efficiency height of the yellow sticky trap on attraction $B$. tabaci through comparison between four heights $(2 \mathrm{~m}, 1.5 \mathrm{~m}, 1 \mathrm{~m}$ and $0.5 \mathrm{~m}$ ) above the ground. And this experiment was carried out on squash plants during (April - Mai) at both the two tested seasons.

Data tabulated in Table (2) showed mean numbers and statically analysis of B. tabaci which caught by yellow sticky traps which have different heights $(2 \mathrm{~m}, 1.5 \mathrm{~m}, 1 \mathrm{~m}$, and $0.5 \mathrm{~m})$, respectively above the ground in the greenhouses squash at both the two tested seasons 2017 , 2018.

Table 2: Mean numbers of B. tabaci which caught by yellow sticky traps, which have different heights on squash plants at both the two successive seasons

\begin{tabular}{|c|c|c|c|c|c|c|}
\hline \multirow{2}{*}{ Trap height } & \multicolumn{5}{|c|}{ Mean numbers of Bemisia tabaci } \\
\cline { 2 - 7 } & \multicolumn{3}{|c|}{2018} \\
\cline { 2 - 7 } & Arkan & Sama 740 & Andro 174 & Arkan & Sama 740 & Andro 174 \\
\hline $\mathbf{2 m}$ & $13.8^{\mathrm{b}}$ & $14.2^{\mathrm{b}}$ & $15.9^{\mathrm{b}}$ & $12.5^{\mathrm{b}}$ & $13.2^{\mathrm{a}}$ & $14.2^{\mathrm{b}}$ \\
\hline $\mathbf{1 . 5 m}$ & $10.7^{\mathrm{b}}$ & $12.9^{\mathrm{b}}$ & $13.3^{\mathrm{b}}$ & $9.7^{\mathrm{b}}$ & $10.4^{\mathrm{b}}$ & $12.9^{\mathrm{b}}$ \\
\hline $\mathbf{1 m}$ & $8.2^{\mathrm{b}}$ & $10.5^{\mathrm{b}}$ & $11.9^{\mathrm{b}}$ & $6.5^{\mathrm{b}}$ & $8.9^{\mathrm{c}}$ & $9.8^{\mathrm{c}}$ \\
\hline $\mathbf{0 . 5 m}$ & $6.9^{\mathrm{b}}$ & $8.9^{\mathrm{b}}$ & $9.1^{\mathrm{b}}$ & $5.8^{\mathrm{b}}$ & $6.7^{\mathrm{a}}$ & $8.3^{\mathrm{d}}$ \\
\hline $\mathbf{F}$ & $\mathbf{6 3 1 . 2 1}$ & $\mathbf{5 6 7 . 0 3}$ & $\mathbf{6 8 5 . 2 5}$ & $\mathbf{3 2 4 . 0 3}$ & $\mathbf{6 5 4 . 7 3}$ & $\mathbf{2 6 5 . 5 3}$ \\
\hline L.S.D & $\mathbf{1 . 1 6 8 2}$ & $\mathbf{1 . 1 5 5 2}$ & $\mathbf{1 . 1 9 8 2}$ & $\mathbf{1 . 1 9 2 1}$ & $\mathbf{1 . 1 3 3 4}$ & $\mathbf{1 . 2 8 2 3}$ \\
\hline
\end{tabular}

Means within columns bearing different subscripts are significantly different $(P<0.05)$

Results showed that the yellow traps which have height $2 \mathrm{~m}$ above the ground more efficiency than others which have $(1.5 \mathrm{~m}, 1 \mathrm{~m}$, and $0.5 \mathrm{~m})$, above the ground respectively. Whereas for the yellow sticky traps which have $2 \mathrm{~m}$ above the ground the mean numbers of $B$. tabaci which attracted to the traps on the three squash varieties (Arkan), (Sama 740) and (Andro 147) at both of the two tested seasons 2017 and 2018 were (13,8@ 12.5), (14,2@ 13.2) and (15,9@14.2) adults/trap, respectively. For the yellow sticky traps which have $1.5 \mathrm{~m}$ 
above the ground the mean numbers of $B$. tabaci which attracted to the traps on the three squash varieties at both of the two tested seasons were (10,7@ 9.7), (12.9@ 10.4) and (13.3@12.9) adults/trap, respectively. For the yellow sticky traps which have $1 \mathrm{~m}$ above the ground the mean numbers of $B$. tabaci which attracted to the traps on the three squash varieties at both of the two tested seasons were (8.2@6.5), (10.5@8.9) and (11.9@ 9.8) adults/trap, respectively. For the yellow sticky traps which have $0.5 \mathrm{~m}$ above the ground the mean numbers of $B$. tabaci which attracted to the traps on the three squash varieties at both of the two tested seasons were (6.9@ 5.8), (8.9@ 6.7) and (9.1@ 8.3) adults/trap, respectively.

Statically analyses showed that were highly significant differences between mean numbers of $B$. tabaci, which attracted to the yellow sticky traps, which have different heights in both of the two tested seasons.

These results were an agreement with Shen and Ren (2003) in China who reported that the best method to trap B. tabaci adults using a yellow card in the squash field. And reported that the best method was to hang the yellow card vertically between the rows of the squash plants, and the height of the yellow card is almost kept the same as the top of the squash plants. Maolin et al. (2006) reported that trap height showed significant influence on trap catches, which that trap height $1.5 \mathrm{~m}$ above the ground more effective than which $0.5 \mathrm{~m}$ above the ground. And reported also that the height of the trap was effective in controlling the adult population of $B$. tabaci on greenhouse squash. Fu et al. (2015) reported that $B$. tabaci is an important pest on vegetables in greenhouses and studied the yellow sticky cards that were hung in Pepper fields and Cucumber fields. And reported that the best height of yellow sticky cards was top of the Cucumber leaves about $10 \mathrm{~cm}-50 \mathrm{~cm}$ higher than the top of the leaves and the best height of the yellow sticky cards were ranged from $1.5 \mathrm{~m}-2 \mathrm{~m}$ above the ground. Moreover, Dan and Horowitz (1984) found that the efficiency of the yellow trap was high whereas in the open air they flew $>2 \mathrm{~m}$ above the ground.

\section{Third Experiment:}

The third experiment aimed to evaluation efficiency orientation of the yellow sticky trap on attraction B. tabaci through comparison between four orientations (North, South, East and West). This experiment was carried out on squash plants during (June - July) at both the two successive seasons 2017, 2018.

Data tabulated in Table (3) showed mean numbers and statically analysis of B. tabaci which caught by yellow sticky traps which have different orientations (North, South, East, and West) in greenhouses squash during at both the two tested seasons 2017, 2018.

Table (3): Mean numbers of $B$. tabaci, which caught by yellow sticky traps, which have different orientations on squash, plants at both the two tested seasons.

\begin{tabular}{|c|c|c|c|c|c|c|}
\hline \multirow{2}{*}{ Trap orientation } & \multicolumn{5}{|c|}{ Mean numbers of Bemisia tabaci } \\
\cline { 2 - 7 } & \multicolumn{3}{|c|}{2017} & \multicolumn{3}{c|}{2018} \\
\cline { 2 - 7 } & Arkan & Sama 740 & Andro 174 & Arkan & Sama 740 & Andro 174 \\
\hline North & $14.3^{\mathrm{b}}$ & $15.7^{\mathrm{b}}$ & $16.2^{\mathrm{b}}$ & $12.5^{\mathrm{b}}$ & $13.5^{\mathrm{a}}$ & $15.8^{\mathrm{b}}$ \\
\hline South & $15.6^{\mathrm{b}}$ & $17.3^{\mathrm{b}}$ & $14.3^{\mathrm{b}}$ & $13.7^{\mathrm{b}}$ & $15.4^{\mathrm{b}}$ & $15.3^{\mathrm{b}}$ \\
\hline East & $12.7^{\mathrm{b}}$ & $16.2^{\mathrm{b}}$ & $17.5^{\mathrm{b}}$ & $13.9^{\mathrm{b}}$ & $15.6^{\mathrm{c}}$ & $16.4^{\mathrm{c}}$ \\
\hline West & $11.5^{\mathrm{b}}$ & $13.4^{\mathrm{b}}$ & $14.2^{\mathrm{b}}$ & $12.6^{\mathrm{b}}$ & $14.7^{\mathrm{a}}$ & $15.3^{\mathrm{d}}$ \\
\hline F & $\mathbf{6 4 1 . 3 6}$ & $\mathbf{5 6 8 . 0 3}$ & $\mathbf{7 6 5 . 2 5}$ & $\mathbf{6 7 5 . 0 3}$ & $\mathbf{2 5 4 . 7 3}$ & $\mathbf{6 3 5 . 5 3}$ \\
\hline L.S.D & $\mathbf{1 . 1 1 7 2}$ & $\mathbf{1 . 1 2 5 2}$ & $\mathbf{1 . 1 8 2 2}$ & $\mathbf{1 . 1 6 2 1}$ & $\mathbf{1 . 1 5 5 4}$ & $\mathbf{1 . 2 3 2 3}$ \\
\hline
\end{tabular}

Means within columns bearing different subscripts are significantly different $(\mathrm{P}<0.05)$ 
Obtained results and statically analyses showed that were not significant differences between the mean numbers of $B$. tabaci, which attracted the yellow sticky traps which have different orientations in both the two tested seasons.

These results agree with Maolin et al. (2006) who reported that the trap orientation had no effect on trap catches, but traps hanged vertically parallel to plant rows trapped slightly more $B$. tabaci adults than those hanged horizontally. Those authors studied the distribution and daily activities of $B$. tabaci adults in a greenhouse (East-West) oriented were investigated with yellow sticky traps. In addition, they found that no significant differences between East and West orientation of the yellow sticky traps in the Cucumber greenhouse. These results agree with those obtained by Xi et al. (2008) who studied the orientation of the yellow sticky traps on tomato plants in greenhouses. And reported that had no effect of the orientation of the traps (North, South, East and West) on atttactive B. tabaci adults. However, they found that the yellow sticky traps trapped $B$. tabaci adults significantly reduced when the traps were placed parallel to tomato rows more than those placed perpendicular to tomato rows on every sampling date.

\section{REFERENCES}

Abdallah, A.A.; Al-Azzazy, M.M.; Mowafi, M.H.; El- Saiedy,E.M.A.and Pastawy, M.A. (2014). Control of the two - spotted spider mite, Tetranychus urticae Koch on kidney bean and pea plants. Acarines, 8(1): 43 - 48.

Abdein, M.A.E. (2016). Squash plants between classic and modern genetics. MOJ Proteomics Bioinform., 3(1): 14-17

Abdel- Salam, A.L.; Metwally, A.M.; Yousef, A.A.; El- Boghdady, N.A.and Hegab, M. F. A. H. (1982). Mites associated with vegetable plants in Egypt. Proc. $1^{\text {st }}$ Conf. Plant Prot. Res. Inst., 3: 61 - 79.

Burger, Y.; Schwartz, A. and Paris, H.S. (1988). Physiological and anatomical features of the silvering disorder of cucurbita. J. Hort. Sci., 63(3): 635 - 640.

Dan, G. and Horowitz, A. R. (1984).Yellow traps for evaluating the population levels and dispersal patterns of Bemisia tabaci (Gennadius) (Homoptera : Aleyrodidae). Ann. Entomol. Soc. Am. 3(77): 753-759

El-Dars, F.M.S.E.; Rizk, M.A. and Takla, S.S. (2015). Determination of chlorofenapyr residues in squash during crop production cycle. Egypt.Acad. J. Biolog. Sci., 5 (1): 27 32.

Faris, F.S.; Habashy, N.H. and Iskandar, A.K.F. (2004): Relationship between infestation with different stages of the spider mite, Tetranychus urticae Koch on fifteen tomato varieties and plant agewith special reference to vegetative and yield physical characters. J.Agric. Sci.Mansoura Univ., 29 (6): 3567 - 3579.

Fu, C.; Jian, H. and Ai, M. (2015). The comparison of the effects of sex attractant and yellow sticky card to Bemisia tabaci (Gennadius) on vegetables in greenhouses. Journal of Biosafety 1(12), 306-309

Gong, Y.; Shi, B.; Wei, S. and Kang, Z. (2011). Study on attractive effects of different colors on Q- type Bemisia tabaci. Northern Horticulture 45(5): 346-353

Heikal, I.H. and Ali, F.S. (2000): Mass rearing of the predaceous mite, Phytoseiulus macropilis (Banks) (Acari: Phytoseiidae). Egypt. J. Agric. Res., 78 (4):1477-1483.

Ibrahim, M.M.S. (2005). Studies on some integrated control practices for the two- spotted spider mite, Tetranychus urticae Koch on cantaloupe crop. Ph. D. thesis. Fac.of Environ. Agric. Sci; Suez Canal University.110 pp.

Kherebe, A.H.; Mohamed, S.S.; Beha'a El-Din, S.A. and Radwan, A.A.(1984). Susceptibility of some cucumber and squash cultivers to aphids and spider mites infestation under 
natural conditions. Bull. Fac. Of Agric., Cairo Univ., 35 (3): 1727 - 1736

Maolin, H.; Wei, L. and Jihui, W. (2006). Trap catches and control efficiency of Bemisia tabaci (Homoptera- Aleyrodidae) adults in greenhouse by yellow sticky traps. Zhonggue Kexue 39(9): 1934-1939

Masaki, M.; Hayase, T.; and Miyajin, S. (1991). Notes on eight species of spider mites and predacious thrips intercepted on squash imported from USA, Mexico, Colombia and New Zealand. Res. Bull. of the Plant Pro. Serv., Japan, 27(3): 107-114

Polston, J.E.; de Barro, P. and Boykin, L.M. (2014). Transmission specificities of plant viruses with the newly identified species of the Bemisia tabaci species complex. Pest Manag. Sci., 70(5): 1547-1552.

SAS Institute (1988): SAS/STAT User Guide, Ver. 6. 03. SAS Institute Inc., Cary, North Carolina.

Shehata, S.M.; Saleh, S.A. and Junge, H. (2009). Response of sexual expression and productivity of squash plants to some biofertilizer treatments. Egypt J. Appl. Sci., 20 (12B): 680-690.

Shen, B. and Ren, S. (2003). Yellow card traps and its effects on population of Bemisia tabaci. Journal of South China Agricultural University 24(4): 40- 43

Soon, D.; Hyun, J.; young, N. and Yeong, H. (2015). Yellow sticky card offers composite attractiveness to western flower thrips and greenhouse whitefly. Journal of Entomolgy and Zoology Studies 3(4): 110- 113

Xi, S.; Wen. J.; Wei, H. and Yi, C. (2008). Population Suppression of Bemisia tabaci (Hemiptera: Aleyrodidae) using yellow sticky traps on tomato plants in greenhouses. Insect Science 15(4): 263 - 270

Yao, S. and Zheng, Y. (2008). Study on the tropism of Bemisia tabaci imagoes to different colors and the distribution of the trapped imagoes on yellow board. Acta Agriculture Shanghai 52(3): 435 - 439. 


\title{
ARABIC SUMMARY
}

تقييم فاعلية المصائد اللاصقة فى جذب حشرة الأبابة البيضاء Bemisia tabaci (Gennadius) على نباتات الكوسة تحت ظروف الصوب البلاستيكية

\author{
أمنة محمد حسن مقلا \\ معهد بحوث وقاية النباتات ـ مركز البحوث الزر اعية ـ الدقى ـ الجيزة ـ مصر
}

أجريت هذه التجارب بغرض تقييم فاعلية المصائد اللاصقة فى جذب حشرة الذبابة البيضاء Butaisia

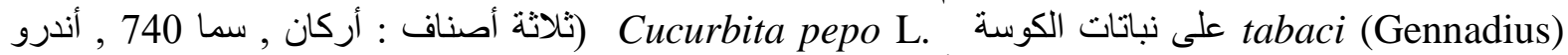

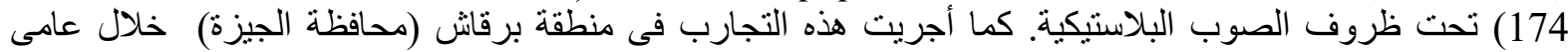

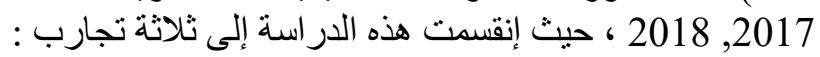

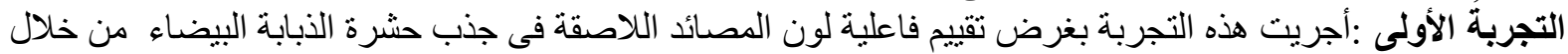

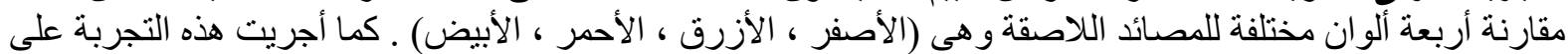

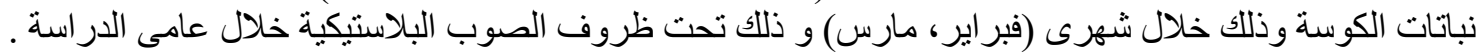

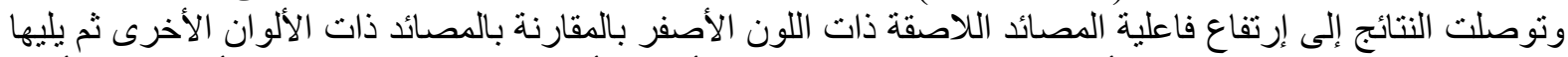

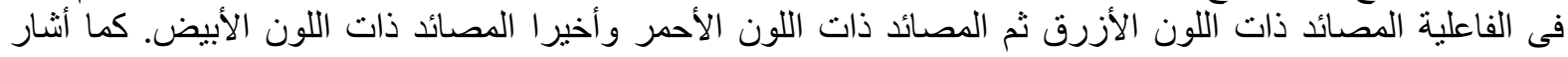

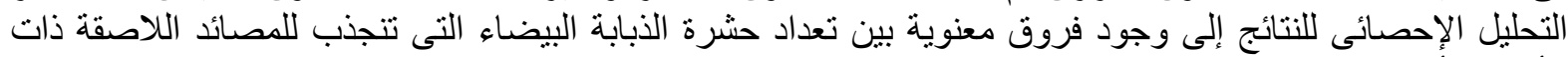

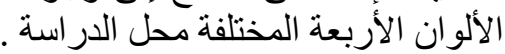
التجرية الثانية :أجريت هذه التجربة بغرض تقييم فاعلية إرتفاع المصائد الصفراء اللاصقة في جذب حشرة الذبابة

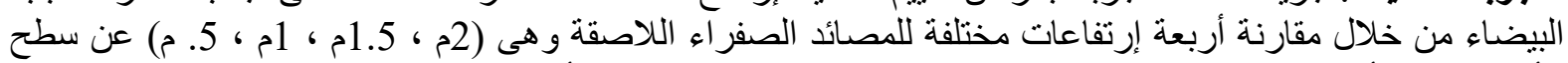

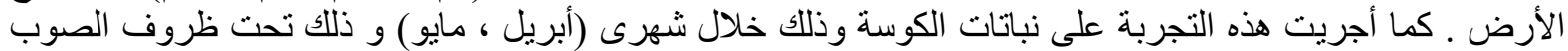

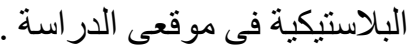

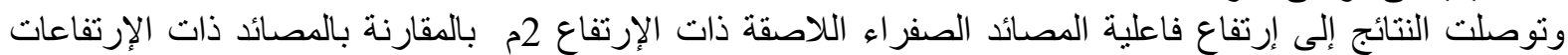

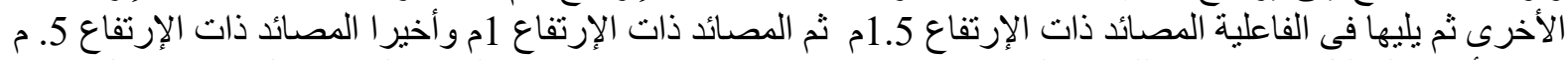

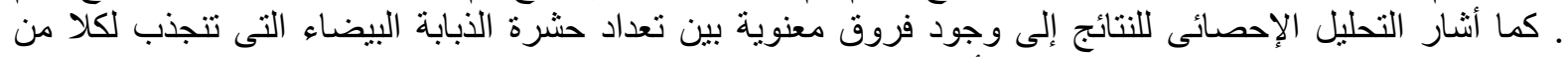

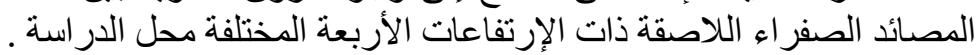

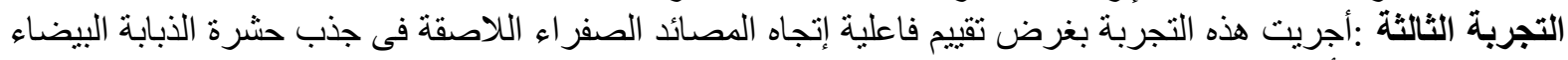

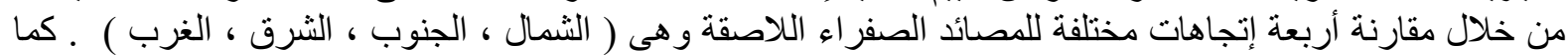

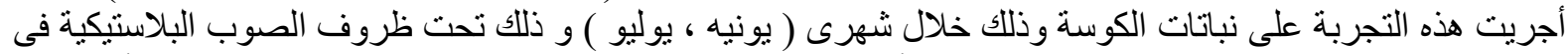

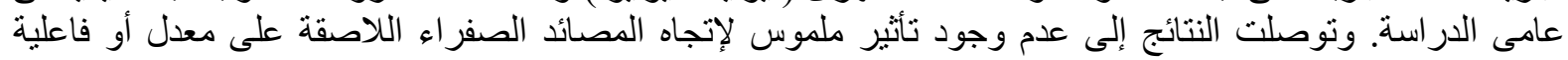

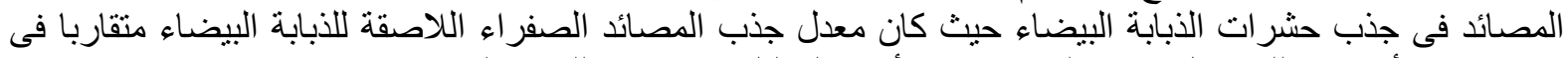

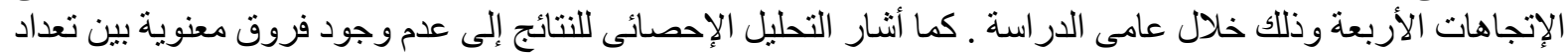

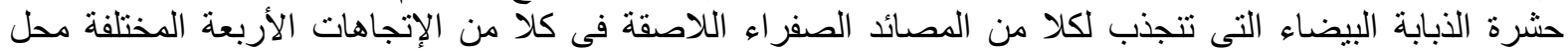

